Eduvest - Journal of Universal Studies

Volume 1 Number 12, December 2021

p- ISSN 2775-3735 e-ISSN 2775-3727

\title{
IMPLEMENTATION ANALYSIS OF ISAK 35 IN FINANCIAL REPORTING OF THE GMIT CHURCH IN INDONESIA
}

\author{
Linda Lomi Ga, Yohana Febiani Angi, Siprianus G. Tefa \\ Nusa Cendana University, Indonesia \\ E-mail: linda.ga@staf.undana.ac.id, yfangi@staf.undana.ac.id, \\ siprianus.tefa@staf.undana.ac.id
}

\begin{tabular}{|c|c|}
\hline ARTICLE INFO & ABSTRACT \\
\hline $\begin{array}{l}\text { Received: } \\
\text { November, } 26^{\text {th }} \\
2021 \\
\text { Revised: } \\
\text { December, 17th } \\
2021 \\
\text { Approved: } \\
\text { December, 19th } \\
2021\end{array}$ & $\begin{array}{l}\text { The church as a non-profit organization also deals with } \\
\text { financial management because it gets resources to carry } \\
\text { out its operations in the form of donations from the } \\
\text { congregation and donors. Therefore, the church needs to } \\
\text { implement good financial management through financial } \\
\text { reporting according to the Interpretation of Financial } \\
\text { Accounting Standards (ISAK) No. 35. in financial } \\
\text { management so as to provide accurate information on } \\
\text { financial position, performance, and cash flows as } \\
\text { material for evaluation and making appropriate decisions. } \\
\text { Through a joint decision with the GMIT Churches in } \\
\text { Indonesia in the annual synod meeting, it has been } \\
\text { recommended to carry out financial reporting according } \\
\text { to applicable standards, but in the realization the } \\
\text { implementation is still in the stage of revamping and } \\
\text { preparing Human Resources as managers and readiness } \\
\text { of financial data information. This study aims to analyze } \\
\text { the implementation of ISAK } 35 \text { in financial reporting at the } \\
\text { GMIT church in Indonesia. The method used is qualitative } \\
\text { descriptive analysis. The result of the research is that } \\
\text { GMIT churches in Indonesia have not implemented } \\
\text { financial reporting according to ISAK Standard No. } 35 \\
\text { because the church is still in the process of administrative } \\
\text { reform and updating of church asset data and the church }\end{array}$ \\
\hline & $\begin{array}{l}\text { Linda Lomi Ga, Yohana Febiani Angi, Siprianus G. Tefa (2021). } \\
\text { Implementation Analysis of Isak } 35 \text { In Financial Reporting of The } \\
\text { GMIT Church in Indonesia. Journal Eduvest. 1(12): 1573-1578 }\end{array}$ \\
\hline $\begin{array}{l}\text { How to cite: } \\
\text { E-ISSN: } \\
\text { Published by: }\end{array}$ & $\begin{array}{l}2775-3727 \\
\text { https://greenpublisher.id/ }\end{array}$ \\
\hline
\end{tabular}




\begin{tabular}{|c|c|}
\hline & $\begin{array}{l}\text { has limited human resources for managing church } \\
\text { finances. By conducting training in the form of } \\
\text { socialization and the practice of preparing financial } \\
\text { reports, it will help the church overcome church problems } \\
\text { and obstacles in carrying out financial reporting according } \\
\text { to financial standards. }\end{array}$ \\
\hline KEYWORDS & $\begin{array}{l}\text { Non-Profit Organizations, Financial Statements, Church, GMIT } \\
\text { Synod, ISAK } 35\end{array}$ \\
\hline (cc) (†) & $\begin{array}{l}\text { This work is licensed under a Creative Commons } \\
\text { Attribution-ShareAlike } 4.0 \text { International }\end{array}$ \\
\hline
\end{tabular}

\section{INTRODUCTION}

A not-for-profit organization is an organization whose principal amount is for a commercial purpose, without any concern for profit-seeking matters (Leff, 2018). The characteristics of non-profit organizations are different from business organizations. The main fundamental difference lies in the way non-profit organizations obtain the resources needed to carry out their various operating activities that do not expect repayment or economic benefits that are proportional to the amount of resources provided. As a result of these characteristics, in non-profit organizations certain transactions arise that rarely or even never occur in business organizations, such as receiving donations (Wibisono \& Setyohadi, 2017). Religious institutions, public school hospitals and organizations that include volunteer services are examples of non-profit organizations (Yogev, 2021).

The church is a non-profit organization or an organization that was not established for the purpose of making profit which also deals with financial management (Shamsutdinova, Tishkina, Galeeva, \& Khasanova, 2020). Religious organizations such as this church get their resources to carry out their operational activities from contributions from members (congregations) and from other donations and of course not expect reward (Sulkowski \& Ignatowski, 2020). As business organizations pay attention to their financial statements, so do not-for-profit organizations (Beer \& Micheli, 2017). The church needs to pay attention to its financial statements as accountability so that users of these financial statements can understand the extent of the financial condition of the organization.

In general, the purpose of financial statements is to provide information about the financial position, performance and cash flows that are useful for the majority of users of financial statements in order to make economic decisions and demonstrate management's stewardship of the users of the resources entrusted to them. Therefore, the Church also needs to implement good financial management to produce accurate information (De Graaf, 2020). Accurate information can be obtained by applying the accounting process in the processing of church finances. The functions of oversight, planning and decision making are accounting roles that have a good influence on church financial management (Appiadu, 2019).

Like companies in general, accountability in non-profit organizations is also very necessary. Accountability within the church is contained in the ministry by recording financial statements, reporting and evaluating performance (Rapani \& Malim, 2020). According to Mardiasmo (2004), accountability is defined as the relationship between the party who controls and regulates the entity and the party who has formal power over the controlling party (Suriana, 2021). Financial accountability in religious organizations can 
be interpreted as the obligation of the holder of the trust to give accountability to the party giving the trust (ummah/donor) who has the right to ask for accountability for the use of these funds. Therefore, it is very important to apply accountability in organizations.

The churches that will be investigated in this research are the GMIT Churches which are members of the GMIT SYNOD. GMIT is managed according to the Synodal Presbyteral system with congregations, Klasis, and synods as its image. The fellowship of these churches is spread to various regions in Indonesia. is part of the GMIT Synodial which of course expects good financial management performance. However, there are some problems that often occur in the management of the church's own finances and these problems are often not noticed by the responsible parties (Alexander, 2018). In its financial management, the church has not yet implemented an accounting system for its financial reporting. This is in line with the treasury rules regulated in the GMIT Basic Rules in Chapter XII article 5, namely the management and utilization of the GMIT treasury is carried out in an integrated, open, economical, and accountable manner in accordance with the GMIT basic regulations and is monitored regularly and regularly by the GMIT synod. Based on previous research conducted by Selan and Ga (2018), the financial statements of the GMIT Synod are not accountable and transparent and are made in accordance with the preparation regulations which are regulated separately by the synod. However, the recommendations of the XXXIII Synod Session in LobalainRote Ndao Regency in 2015 recommended that the Synod Assembly establish an accounting system that refers to PSAK 45, in 2016 starting with the making of SOPs, socialization and training. Its use took effect in 2018. Meanwhile, PSAK 45 has been updated to ISAK 35 and its use will be implemented in 2020. The purpose of this study is to identify and explain the Implementation of ISAK 35 in Financial Reporting at the GMIT Church in Indonesia.

\section{RESEARCH METHOD}

This research approach uses a quantitative descriptive method with a case study on a church in the GMIT synod. Sources of data in this study are primary data and secondary data. Primary data in the form of interviews with research informant questionnaires on the application of financial reports with ISAK 35 standards, secondary data in the form of church financial reports provided by the Synod. The data collection techniques used are: (1) in-depth interviews (In dept Interview); (2) Documentation and (3) Literature Study. Research informants in this study were all treasurers of GMIT churches in Indonesia. This study uses an interactive model in the analysis of interview data. The interactive model uses 4 components, namely (1) data collection, (2) data reduction, (3) data presentation, and (4) conclusion or verification (Miles and Huberman, 1984; Sugiyono, 2007). Data was collected through interviews and documentation. Interviews were conducted with personal interviews, namely face-to-face interviews with respondents (Jogiyanto, 2004). The results of the interviews were recorded with a tape recorder and copied in the form of a transcript. Data reduction was carried out by codification and axial coding of the interview results. The data obtained from the interviews were copied in the form of transcripts, analyzed and given a certain code for each phrase, sentence, or paragraph based on the topic. The coded data is grouped into certain categories, then the relationship between categories is searched (axial coding). The data reduction process was carried out continuously during the research. The presentation of the data is done with a narration to organize the data. The reduced data is presented in the form of narratives and drafts of the preparation of church financial reports according to ISAK 35 standards. Through the presentation of data with narratives 
and drafts of financial statements according to data standards, the data will be organized, arranged in the form of draft financial statements, so that they are easy to understand. Conclusion drawing and verification is carried out based on the process of data reduction and presentation. The collection is supported by valid and consistent evidence throughout the research process. Conclusions will answer the problem formulation that was set from the start.

\section{RESULT AND DISCUSSION}

One form of accountability for non-profit organizations to stakeholders is related to financial reports that follow certain standards. This is of course reasonable because through the financial reports the stakeholders can use it as an instrument to assess the accountability of the board/management for the tasks, obligations and performance assigned to them. The Synod of the Evangelical Christian Church in Timor (GMIT Synod) is the only organization that accommodates Protestant churches within GMIT, spread over 52 classes as of April 2020 covering the former residency of Timor (Sumbawa, Flores, Alor, Timor, Rote, methamphetamine - except Sumba). Like other non-profit organizations, the GMIT Synod in carrying out its organizational wheels is also inseparable from financial management so that GMIT requires directed and more measurable guidelines in the preparation and accountability of financial statements to provide a more directed preparation guideline for non-profit entities in preparing financial statements as well as distinguishing between the preparation of financial statements with profit-oriented organizations/entities, the Indonesian Institute of Accountants (IAI) since 1997 has been regulated by the Statement of Financial Accounting Standards (PSAK) 45. However, starting in 2019, PSAK 45 has been replaced with the Interpretation of Financial Accounting Standards (ISAK). 35. DSAK IAI observes the opinion and fact that the development of non-profit-oriented entities in Indonesia requires a review of the financial statement arrangements for non-profit-oriented entities. Moreover, PSAK 45 has not been reviewed for a long time, while the presentation of financial statements after convergence to International Financial Reporting Standards (IFRS) has had significant changes, for example with the presence of other components of comprehensive income in the Comprehensive Income Statement. With the issuance of this new regulation, nonprofit organizations prepare their financial statements in accordance with ISAK 35. However, the emergence of this new regulation makes it difficult for non-profit organizations including GMIT to apply because many non-profit organizations do not have an accounting background, making it difficult to implement. The presentation of financial statements at GMIT is often faced with a dilemma between being more professional and accountable according to standards or staying afloat by relying on mutual trust between fellow administrators or managers. Through this research, interviews were conducted with several informants who were represented from several GMIT churches (Fraiser et al., 2017). The average education of the informants is a bachelor's degree and some even master's and doctoral degrees. The interviewed informants work as church financial managers with the professions of Chairperson of the Congregational Council (pastor), and deputy secretary, as well as the general treasurer of the church (Irawan, Mustikasiwi, Djap, Hermawati, \& Santosa, 2021). In the GMIT church financial system, the treasury is carried out only by the general treasurer, the categorical field of service is only as a money registrar. The financial system is centered on the general treasury of the church. So that every receipt and expenditure at the rayon or categorical level is carried out centrally and in one door. Congregations and church financial managers are aware of the importance of church financial management because of the form of church accountability as a public organization, and based on church 
treasury regulations regarding church financial management accountability (Akotia, 2019). Transparent and accountable financial reporting will result in the congregation's confidence in the church's financial management.

The congregation knows and is aware of the importance of church financial reporting standards in accordance with the standards-based financial reporting recommendations that apply at the 2015 GMIT XXXIII and XXXIV Synod Assembly in Kupang (at the Paul Kupang congregation). However, in its implementation, the synodial party is constrained by human resources and the budget in realizing this in the church treasury system. This is important because the financial system at the GMIT church refers to the GMIT church treasury system guidelines. If it has been entered into the church treasury system, it will be carried out or adopted by all GMIT churches in Indonesia. The GMIT Synod's rules for financial reporting standards for GMIT churches are referring to several regulatory guidelines from the synod, namely the 2012 Treasury Fundamental Regulations, the GMIT Treasury Manual, and periodic internal audits through BP3J. Some of these guidelines are the reference guidelines for financial management and financial accountability of each GMIT church. There are several types of church financial accountability reports, namely reports on expenses and cash income for routine and development funds on a regular basis (Widiastuti, 2018). For weekly accountability reports, it is carried out in a simple way through the congregation's news which is carried out during the main service on Sundays. Meanwhile, financial reports are carried out periodically in the semi-annual period and annual. In fact, some churches in rural areas do not even make regular financial reports, this is due to busy services and limited human resources (Human Resources) in rural areas. Many of the congregations and managers of GMIT churches are not even aware of the existence of the new ISAK 35 reporting standard to replace the old PSAK 45 reporting standard so that with the limited information and human resources conditions, the management really expects information support from academics. This academic support is expected to be able to synergize with the GMIT synod so that this application is top-down and recommended by the GMIT sonode to be applied to every eye of the congregation is comprehensive and generally applicable. So the analysis obtained from the answers to interviews conducted with several GMIT church informants concluded that GMIT churches have not implemented ISAK 35 in church financial reporting because they have not received information related to financial reporting standards according to ISAK 35 standards from the GMIT synod because they have not been included. into the church treasury system, so cooperation and synergy are needed from the academic side and the GMIT Synod. In addition, the limited human resources for managing church finances are an obstacle in realizing this, because the church is a religious organization so that the salaries and income of employees and administrators are not a priority because they are considered as a form of religious service from individual church managers so that the church has limited human resource competencies from volunteers who work. there is. This can be minimized by conducting training on the needs of church financial managers so that they can contribute to the church.

\section{CONCLUSION}

The results of this study conclude several things, as follows: GMIT churches have not implemented ISAK 35 in the presentation of financial statements, even though it has been planned in previous years. Barriers to the implementation of ISAK 35 in financial reporting are due to the condition of inadequate Human Resources and not yet supported by training and education as well as the busyness of church managers in carrying out spiritual services. The synod and the church want synergy between universities and the 
GMIT Synod for the formulation of ISAK 35 standards in financial reporting as contained in the ecclesiastical treasury guidelines.

\section{REFERENCES}

Akotia, Y. A. (2019). Financial Management of Churches in Ghana: A Case Study of Legon Interdenominational Church. University of Ghana.

Alexander, Jeffrey C. (2018). The societalization of social problems: Church pedophilia, phone hacking, and the financial crisis. American Sociological Review, 83(6), 10491078.

Appiadu, E. T. (2019). Evaluating the financial management practices in the sustainability of Pentecostal-Charismatic churches. North-West University.

Beer, Haley Allison, \& Micheli, Pietro. (2017). How performance measurement influences stakeholders in not-for-profit organizations. International Journal of Operations \& Production Management.

De Graaf, Nan Dirk. (2020). 9. Secularization: Theoretical Controversies Generating Empirical Research. In The Handbook of Rational Choice Social Research (pp. 322-354). Stanford University Press.

Fraiser, Louis Gabaude, Gloor, Frederic, Goodman, Jim, Greenaway, Deborah, Hohler, Reinhard, Melton, John, Myat, Mon Mon, Morel, Patrick, Hinsuiranan, Narumit, \& Olson, Debra. (2017). Informal Northern Thai Group Bulletin.

Irawan, Dadang, Mustikasiwi, Anggaripeni, Djap, Wylen, Hermawati, Oki, \& Santosa, Erwin. (2021). Pastors and Treasurers: A Case Study of Financial Management in Christian Organization. Integritas: Jurnal Teologi, 3(1), 213-226.

Leff, Benjamin M. (2018). The boundary between the not-for-profit and business sectors: Social enterprise and hybrid models. In Research Handbook on Not-For-Profit Law. Edward Elgar Publishing.

Rapani, Nor Hanani Ahamad, \& Malim, Tanjong. (2020). The correlation between internal control components and the financial performance of iraqi banks a literature review.

Shamsutdinova, V. V, Tishkina, T. V, Galeeva, V. R., \& Khasanova, L. R. (2020). Foreign Non-Profit Organizations: Analysis, Comparison, and Experience. First International Volga Region Conference on Economics, Humanities and Sports (FICEHS 2019), 218-221. Atlantis Press.

Sulkowski, Lukasz, \& Ignatowski, Grzegorz. (2020). Impact of COVID-19 pandemic on organization of religious behaviour in different Christian denominations in Poland. Religions, 11(5), 254.

Suriana, Suriana. (2021). The Influence Of Accountability And Transparency Of Financial Management Of Village Funds On Village Government Performance In Kotarih Baru Village Kotarih District Sergai Regency. International Journal of Educational Review, Law And Social Sciences (IJERLAS), 1(1), 53-66.

Wibisono, Yohanes Priadi, \& Setyohadi, Djoko Budiyanto. (2017). Accounting information system for nonprofit organization based on PSAK 45 standards. 2017 2nd International Conferences on Information Technology, Information Systems and Electrical Engineering (ICITISEE), 136-140. IEEE.

Widiastuti, Fetia Nursih. (2018). Violence Againts Young Married Women: Association Between Child Marriage And Intimate Partner Violence In Indonesia. Compiled Papers, 27, 46.

Yogev, Dikla. (2021). Community-Society Equilibrium: Religious Organizations in the Service of a Secular State. Contemporary Jewry, 1-18. 